\title{
Standardization of Loop mediated isothermal amplification for detection of $D$. nodosus and $F$. necrophorum causing footrot in sheep and goats
}

kavitha madineni

Sri Venkateswara University

N. Vinod Kumar ( $\sigma$ vinodkumarnagaram@gmail.com )

Sri Venkateswara Veterinary University

\section{Research Article}

Keywords: Footrot, D. nodosus, F. necrophorum, LAMP, Duplex PCR, sheep and Goat

Posted Date: August 23rd, 2021

DOI: https://doi.org/10.21203/rs.3.rs-748740/v1

License: (c) (i) This work is licensed under a Creative Commons Attribution 4.0 International License. Read Full License 


\section{Abstract}

The Loop Mediated Isothermal Amplification (LAMP) was standardized for rapid detection of $D$. nodosus and $F$. necrophorum. A total of 250 foot swabs (200) were screened from sheep and (50) were from goats from different districts of Rayalaseema viz., Chittoor, Nellore, Kadapa, Anantapur. Out of 250 samples 75 (30.0\%) and 85 (34.0\%) were positive for D. nodosus and F. necrophorum respectively. All the 250 samples were screened individually for both the organisms by LAMP. Among them, $104(41.6 \%)$ were found to be positive for $D$. nodosus and 120 (48.0\%) were positive for F. necrophorum. The efficacy of LAMP in terms of sample DNA detection limit was compared with the PCR by using standard dilutions of DNA extracted from $D$. nodosus and $F$. necrophorum cultures. The detection limit was found to be higher than PCR for both the organisms. The sensitivity of LAMP is compared with PCR by targeting 16S rRNA gene of $D$. nodosus and IktA gene of $F$. necrophorum. In case of $D$. nodosus, out of 250 samples, $75(30.0 \%)$ were positive by PCR and $104(41.6 \%)$ were positive by LAMP. Among 250 samples, 85 (34.0\%) were positive by PCR and 120 (48.0\%) were positive by LAMP in case of $F$. necrophorum. The LAMP was found to be more sensitive than PCR in detecting the organisms with high statistical significance.

\section{Introduction}

livestock is the major contributing factor for India being a developing country which mainly depends on agriculture as the main source of income. Sheep and goats play an important role in the livelihood of many small and marginal farmers and landless laborers. Footrot has been reported previously from temperate climates of Jammu and Kashmir alone for the last 18 years In India, The disease was reported later on from unusual tropical climate of Andhra Pradesh and Tamil Nadu states of southern India. Outbreaks of footrot were being reported regularly from Andhra Pradesh affecting sheep and goat population (Wani et al. 2007; Farooq et al. 2010; Thomas et al. 2011; Sreenivasulu et al. 2013; Kumar et al. 2013; Kumar et al. 2015; Kumar et al. 2016 ). At present, footrot is endemic disease in the states of Jammu and Kashmir, Uttar Uradesh and Himachal Pradesh, Andhra Pradesh.

Footrot is mainly caused by the synergistic action of Dichelobacter nodosus formerly (Bacteroides nodosus) as the primary transmitting agent, Fusobacterium necrophorum as secondary pathogen. Both are anerobic, gram-negative, rod shaped bacterium with characteristic knobs at each end and is fimbriated (Sreenivasulu et al. 2013). Clinically severe disease is referred as the virulent footrot, while milder mainly interdigital form of the disease refers to benign footrot, based on the production of thermostable proteases or the integrase A gene(intA), which relate to the corresponding forms of the disease (Cheetham et al. 2006). The term intermediate footrot is used to refer forms of footrot that are in between the two forms. The organism Dichelobacter nodosus was classified as 10 serogroups (A-I and M) identified based on K-type agglutination of the surface antigens. These serogroups are further divided into 19 serotypes based on cross absorbtion tests. Type IV fimbriae and extracellular proteases are essential for virulence of $D$. nodosus (Kennan et al. 2001; Kennan et al. 2010). Class I fimbriae included those of serogroups A, B, C, E, F, G and I, while class II contained in serogroups $D$ and $H$. The two sets of fimbriae are also distinguished by their disulphide loop profile Elleman (1988). 
Fusobacterium necrophorum subsp. necrophorum produce a secreted protein leukotoxin (IktA) a major virulence factor along with other potent virulence factors such as leukotoxin, lipopolysaccharide and hemagglutinin (Tan et al. 1992; Amoako et al. 1993; Narayanan et al. 2001; Amit Kumar et al. 2013).

Diagnosis of footrot disease by isolation of the organism, followed by antigenic analysis using serological procedures may take 3-4 weeks. Alternatively PCR based methods without need to culture have been used for initial detection (La Fontaine et al. 1993) and characterization (Dhungyel et al. 2002) of D. nodosus. Nucleic acid amplification by PCR is one of the most valuable alternative for the detection of $D$. nodosus causing footrot. High precision instruments and standardized protocols are essential for PCR based methods for detection and confirmation of the amplified products. In addition, PCR is not suitable to adopt for routine clinical use. The loop-mediated isothermal amplification (LAMP) assay may fulfill all the above parameters for which it can be used as low cost alternative for detection of organisms causing footrot.

\section{Materials And Methods}

\section{Collection of samples}

A total of 250 footswabs were collected from the flocks of sheep and goats in different districts of Rayalaseema regions (Chittor, Kadapa, Nellore, Ananthapur) where the prevalence of footrot is high (Table 1). Among them 200 were collected from sheep and 50 are from goats. Samples were collected from the animals showing the symptoms like lameness, decreased body weight, infectious dermatitis of the inter digital skin with a grey scum, pungent and characteristic rotting smell.

\section{Table 1 Details of Samples collected}

\begin{tabular}{|llllll|}
\hline S.No & Name of the district & \multicolumn{3}{l}{ No. of flocks visited } & \multicolumn{3}{c|}{ No. of samples collected } \\
\cline { 3 - 6 } & & & Sheep & Goats & Total \\
\hline 1 & Chittor & 40 & 107 & 15 & 122 \\
\hline 2 & Kadapa & 15 & 38 & 9 & 47 \\
\hline 3 & Nellore & 6 & 35 & 12 & 47 \\
\hline 4 & Ananthapur & 5 & 20 & 14 & 34 \\
\hline & Total & 66 & 200 & 50 & 250 \\
\hline
\end{tabular}

\section{DNA extraction by boiling method}

Swabs collected from the interdigital space of the hooves were suspended in $150 \mu \mathrm{L}$ of sterile phosphate buffered saline (PBS) and the suspension was prepared by gentle vortexing for five minutes. The suspension was boiled for ten minutes and then immediately cooled down on ice for 10 minutes. The 
suspension was centrifuged at 10,000rpm for ten minutes. The supernatant was used as DNA. The supernatant along with debris was stored at $-20^{\circ} \mathrm{C}$ for further use. Two microlitre of sample was used as template in PCR (Kumar et al. 2015).

\section{Reference strain}

The F. necrophorum DNA was provided by UNIVERSITY OF WARWICK, London, United Kingdom with Ref no: Fn DSM 21784. D. nodosus DNA was prepared from stock cultures (serogroup I) maintained in this laboratory.

\section{Screening of clinical samples by Duplex PCR}

DNA was extracted by boiling method and all the samples were screened by duplex PCR for the presence of the $16 \mathrm{~S}$ rRNA of $D$. nodosus and $I \mathrm{ktA}$ gene of $F$. necrophorum. The duplex PCR was performed using a thermocycler with a final reaction volume of $25 \mu \mathrm{L}$ containing $2.5 \mu \mathrm{L}$ of Taq buffer (10x); $1 \mu \mathrm{L} \mathrm{of} 25 \mathrm{Mm}$ Mgcl2; $0.3 \mu \mathrm{L}$ of d NTP mix (10mM); $0.6 \mu \mathrm{L}$ of $16 \mathrm{~S}$ rRNA (F+R) (10pmol); $0.6 \mu \mathrm{L}$ of IktA (F+R) (10pmol); 0.5 $\mu \mathrm{L}$ of Taq DNA polymerase $(5 \mathrm{U} / \mu \mathrm{L}) ; 3.0 \mu \mathrm{L}$ of Template DNA and $16.5 \mu \mathrm{L}$ of Nuclease free water. Amplification was obtained with 35 cycles, following the PCR $10 \mu \mathrm{L}$ of amplified products was confirmed by using gel electrophoresis in a 1.5\% agarose gel. The amplified bands were visualized under UV illumination (Harsha, 2019).

\section{Primer designing for LAMP}

The LAMP primers targeting $D$. nodosus $16 S$ rRNA and IktA gene of F. necrophorum were designed by using the LAMP primer design software program Primer Explorer V5, from Ekin Chemical Company, Japan(http://primerexplorer.jp/elamp3.0.0/index.html). A set of four AT rich primers comprising two outer and two inner primers were designed. The two outer primers were known as the forward outer primer (F3) and the backward outer primer (B3) which helps in strand displacement. The inner primers were known as the forward inner primer (FIP) and the backward inner primer (BIP), respectively. FIP contains F1C (complementary to F1), a TTTT spacer and the F2 sequence. BIP contains the B1C sequence (complementary to B1), a TTTT spacer and B2 sequence. The primer details were given in the (Table 2 and Table 3). The primers were procured from Eurofins Genomics India Pvt. Ltd., Bangalore.

\section{Table 2 Primers for $D$. nodosus used in LAMP reaction}




\begin{tabular}{lllllll} 
Label & $\mathbf{5}$ 'position & 3'position & Length & Tm & GC\% & Sequence \\
F3 & 998 & 1017 & 20 & 60 & 0.55 & CCTTCGGGAACTCTGAGACA \\
B3 & 1163 & 1181 & 19 & 59 & 0.53 & GGCCATGATGACTTGACGT \\
\hline FIP & & & 39 & & & $\begin{array}{l}\text { CGCTCGTTGCGGGACTTAACC } \\
\text { GGTGTTGCATGGCTGTCG }\end{array}$ \\
\hline BIP & & & & & & CTTGCCAGCACGTAAAGGTGGG \\
& & & 41 & & & CACCTTCCTCCGGTTTGTC \\
F2 & 1018 & 1035 & 18 & 60 & 0.61 & GGTGTTGCATGGCTGTCG \\
F1C & 1059 & 1079 & 21 & 65 & 0.62 & CGCTCGTTGCGGGACTTAACC \\
\hline B2 & 1138 & 1156 & 19 & 59 & 0.58 & CACCTTCCTCCGGTTTGTC \\
\hline B1C & 1095 & 1116 & 22 & 65 & 0.59 & CTTGCCAGCACGTAAAGGTGGC
\end{tabular}

Table 3 Primers for $F$. necrophorum used in LAMP reaction

\begin{tabular}{|lllllll|}
\hline Label & $\mathbf{5}^{\prime}$ position & 3'position & Length & Tm & GC\% & Sequence \\
\hline F3 & 1523 & 1543 & 21 & 5.62 & 0.38 & AGACAGTGTCAATGAGGAAAT \\
\hline B3 & 1717 & 1734 & 18 & 56.01 & 0.50 & TTCGTACAGCCACACTTC \\
\hline FIP & & & 48 & & & $\begin{array}{l}\text { TGCCACAGAAGCAGAATTATTATGACTA } \\
\text { BIP }\end{array}$ \\
& & & 42 & & & ACAGACTTATTTAGTGTCGG \\
\hline F2 & 1554 & 1576 & 23 & 56.04 & 0.39 & CTAACAGACTTATTTAGTGTCGG \\
\hline F1c & 1598 & 1622 & 25 & 60.68 & 0.36 & TGCCACAGAAGCAGAATTATTATGA \\
\hline B2 & 1699 & 1716 & 18 & 56.43 & 0.56 & CACTTGACGTAGTCGCTC \\
\hline B1c & 1636 & 1659 & 24 & 60.65 & 0.46 & GAAGACTTTCTTCAGGAGTGGAAG \\
\hline
\end{tabular}

\section{Standardization of LAMP reaction}

LAMP reaction was standardized for $16 S$ rRNA of D. nodosus and $I k t A$ gene of $F$. necrophorum. The enzyme Bsm DNA polymerase was procured from Thermo Scientific, Inc. The LAMP was standardized to determine optimum concentrations of primers, enzyme, temperature and time combinations for amplification of target 
genes. For $D$. nodosus a total volume made up to $25 \mu \mathrm{l}$ using nuclease free water with $\mathrm{MgCl} 2(25 \mathrm{mM})-1 \mu \mathrm{l}$; Bsm buffer (×10)-2.5 $\mu \mathrm{l}$; dNTP mix (10 mM)-7.5 $\mu \mathrm{l} ; \mathrm{Bsm}$ DNA polymerase $(8 \mathrm{U} / \mu \mathrm{l})-0.3 \mu \mathrm{l}$; temple (target DNA $)-2 \mu \mathrm{l} ; \mathrm{F} 3(10 \mathrm{pmol} / \mu \mathrm{l})$ - $1 \mu \mathrm{l} ; \mathrm{B} 3(10 \mathrm{pmol} / \mu \mathrm{l})$ - $1 \mu \mathrm{l} ; \mathrm{FIPa}(40 \mathrm{pmol} / \mu \mathrm{l})$ - $4 \mu \mathrm{l} ; \mathrm{BIP}(40 \mathrm{pmol} / \mu \mathrm{l})$ - $4 \mu \mathrm{l} ;$ nuclease-free water $-2.2 \mu \mathrm{l}$. In case of $F$. necrophorum a reaction mixture of $25 \mu \mathrm{l}$ was prepared by using

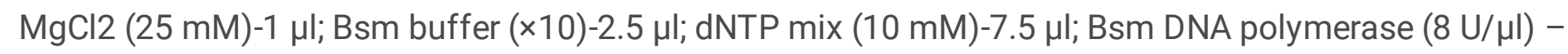
$0.5 \mu \mathrm{l}$; temple (target DNA) - $2 \mu \mathrm{l} ; \mathrm{F} 3(10 \mathrm{pmol} / \mu \mathrm{l})$ - $1 \mu \mathrm{l} ; \mathrm{B} 3(10 \mathrm{pmol} / \mu \mathrm{l})-1 \mu \mathrm{l} ; \mathrm{FIPa}(40 \mathrm{pmol} / \mu \mathrm{l})$ - $4 \mu \mathrm{l}$; $\operatorname{BIP}(40 \mathrm{pmol} / \mu \mathrm{l})-4 \mu \mathrm{l}$; nuclease-free water $-2 \mu \mathrm{l}$.

\section{LAMP amplification}

The LAMP amplification was done in thermal cycler by the following steps with negative controls added with nuclease free water in place of template DNA. In the initial reaction nuclease free water, Bsm buffer ( $\times 10)$, dNTP smix and template were added into ependorff tube with initial denaturation at $95^{\circ} \mathrm{C}$ for $5 \mathrm{~min}$. After chilling the samples for $30 \mathrm{~s}$ to $1 \mathrm{~min}$, outer primers, inner primers and enzyme were added. For $D$. nodosus LAMP reaction was standardised at $60^{\circ} \mathrm{C}$ for 60 min was shown in Fig. 1 followed by enzyme inactivation step for $10 \mathrm{~min}$ at $80^{\circ} \mathrm{C}$. In case of $F$. necrophorum the LAMP reaction was standardized at $56^{\circ} \mathrm{C}$ for 60 min was shown in Fig. 2. The amplified LAMP products were stored at $-20^{\circ} \mathrm{C}$.

\section{Electrophoresis of LAMP products}

LAMP products were subjected to agarose gel electrophoresis in a Genei submerged gel apparatus. Agarose gels were prepared with $2.0 \%$ agarose using $1 \times$ TBE buffer (Tris buffer, Boric acid and EDTA). The LAMP products were mixed with $2 \mu \mathrm{L}$ of $6 \mathrm{x}$ gel loading dye and $10 \mu \mathrm{L}$ of the products were mixed and loaded in each well. Electrophoresis was carried 80 volts for $45 \mathrm{~min}$ at $35 \mathrm{~mA}$. Electrophoresis was stopped when the dye front reached two-third of the gel. Gel was visualized under ultraviolet (UV) transilluminator and photographed with gel documentation system (Alpha Innotech, Alphaimager, HP).

\section{Comparison of efficacy of LAMP with PCR}

The efficacy of LAMP in terms of sample DNA detection limit was compared with the PCR using the standard doubling dilutions of $D$. nodosus culture DNA and $F$. necrophorum DNA provided by UNIVERSITY OF WARWICK, London, United Kingdom with Ref no: Fn DSM 21784. The dilutions were performed with initial ten-fold dilution followed by two-fold dilutions.

\section{Comparison of sensitivity of PCR and LAMP}

All the 250 field samples were tested with LAMP and the results were compared with duplex PCR results. The diagnostic sensitivity of the LAMP was compared with duplex PCR results using Chi square analysis. There is a significant level of difference between the two tests by this it can be concluded that LAMP is more sensitive than PCR in detecting and screening of the clinical samples.

\section{Table 4 Comparison of diagnostic sensitivity of LAMP with PCR}




\begin{tabular}{|lccc|}
\hline & PCR & LAMP & Total \\
\hline D. nodosus positives & 75 & 104 & $\mathbf{1 7 9}$ \\
\hline D. nodosus negatives & 175 & 146 & $\mathbf{3 2 1}$ \\
\hline Total & $\mathbf{2 5 0}$ & $\mathbf{2 5 0}$ & $\mathbf{5 0 0}$ \\
\hline The chi- square statistic with Yates correction is 7.318. & & & \\
Significant at $p<.05$ level. & & & \\
\hline F. necrophorum positives & 85 & 120 & $\mathbf{2 0 5}$ \\
\hline F. necrophorum negatives & 165 & 130 & $\mathbf{2 9 5}$ \\
\hline Total & $\mathbf{2 5 0}$ & $\mathbf{2 5 0}$ & $\mathbf{5 0 0}$ \\
\hline $\begin{array}{l}\text { The chi- square statistic with Yates correction is } 10.128 . \\
\text { Significant } \text { at } p<.05 \text { level. }\end{array}$ & & & \\
\hline
\end{tabular}

\section{Screening of clinical samples by both PCR and LAMP}

All the 250 clinical samples were screened for both Duplex PCR and LAMP as per standard protocol.

\section{Results And Discussion}

A novel nucleic acid amplification LAMP by auto cycling strand displacement DNA synthesis using Bst DNA polymerase large fragment was first designed by Notomi et al. 2000; Mori et al. 2001. The outer LAMP primers could anneal to the complimentary sequence of the double standard DNA in dynamic equilibrium in LAMP reaction mixture at the temperature around $65^{\circ} \mathrm{C}$ to initiate LAMP reaction. Parida et al. (2008) recommended that initial heat denaturation step is not required in LAMP reaction. However initial denaturation step of template DNA was added in the present study to increase the reaction efficiency as recommended by several previous workers (Notomi et al. 2000; Kamachi et al. 2006; Das et al. 2012; Radhika et al. 2016).

For standardization of LAMP different combinations of specific outer and inner primers were tried. Serial dilutions of primers with $10 \mathrm{p} \mathrm{mol} / \mu \mathrm{L}$ of outer primer and the inner primers of $10 \mathrm{p} \mathrm{mol} / \mu \mathrm{L}, 40 \mathrm{p} \mathrm{mol} / \mu \mathrm{L}$ and $80 \mathrm{p} \mathrm{mol} / \mu \mathrm{L}$ were tested. The outer primers concentration of $10 \mathrm{p} \mathrm{mol} / \mu \mathrm{L}$ and $40 \mathrm{pmol} / \mu \mathrm{L}$ of inner primers (FIP and BIP) were found to be optimum for amplification of specific positive LAMP reaction in for D. nodosus and F. necrophorum. Notomi et al. (2000); Radhika et al. (2016) recommended Similar combination of outer primers at $1 / 4$ to $1 / 10$ concentration of the inner primers for optimal amplification. The enzyme Bsm polymerase large fragment with high functional similarity to Bst DNA polymerase was used successfully in the present study, as described by Johnson et al. (2014) to amplify Citrus yellow mosaic badnavirus (CMBV) by LAMP. The LAMP reaction was standardized by using different 
concentrations of the enzyme $0.3 \mu \mathrm{L}, 0.5 \mu \mathrm{L}, 0.75 \mu \mathrm{L}$ and $1 \mu \mathrm{L}$ to test the optimum concentration. The enzyme concentration of $0.3 \mu \mathrm{L}$ was found to be optimum for positive LAMP reaction. Similarly, $0.5 \mu \mathrm{L}$ enzyme concentration was found to be optimum for LAMP reaction to detect $F$. necrophorum from footrot suspected sheep and goat samples. LAMP reaction was standardised at $60^{\circ} \mathrm{C}$ for $60 \mathrm{~min}$ for $D$. nodosus. In case of $F$. necrophorum the LAMP reaction was standardized at $56^{\circ} \mathrm{C}$ for $60 \mathrm{~min}$. Similar combinations of temperature and time ranging from $60-65^{\circ} \mathrm{C}$ were used by several workers for successful LAMP reaction with Bst DNA polymerase (Notomi et al. 2000; Radhika et al. 2016; Zheney et al. 2018; Zhang et al. 2019; Wang et al. 2020).

The efficacy of LAMP in terms of sample DNA detection limit was compared with the PCR by using standard dilutions of DNA extracted from $D$. nodosus cultures. The dilutions were performed with initial tenfold dilution followed by two-fold dilutions. LAMP and PCR was performed with all the dilutions after measuring the DNA concentration using nanodrop spectrophotometer. The PCR could detect up to the dilution of $1: 320(0.7 \mathrm{ng} / \mu \mathrm{L})$, whereas the LAMP could detect up to the dilution of $1: 1280(0.2 \mathrm{ng} / \mu \mathrm{L})$ as presented in Fig. 3. The DNA detection limit of LAMP was found to be higher than PCR. Similarly, for $F$. necrophorum LAMP the detection limit was found to be 1:1280 $(0.0125 \mathrm{ng} / \mu \mathrm{L})$ of DNA dilution, whereas for PCR could detect only up to $1: 320(0.05 \mathrm{ng} / \mu \mathrm{L})$ dilution as shown in Fig. 4. Similar type of sensitivity assay of LAMP was performed by ten-fold dilutions of genomic DNA copies of target species by Sun et al. 2011 and Saxena et al. 2019.

The LAMP test results of 250 samples were compared with duplex PCR test results to determine the diagnostic sensitivity of the LAMP test. Out of 250 samples, 75 were positive for $D$. nodosus by PCR and 104 were positive for LAMP. The chi square calculated value was found to be 7.318. Similarly, for $F$. necrophorum, out of 250 samples 85 were positive by PCR and 120 were positive for LAMP as shown in Fig. 5. The chi square calculated value was 10.128 with significant level of difference between the two tests by this it could be concluded that LAMP is more sensitive than PCR in screening of the clinical samples.

\section{Conclusion}

Further validation and commercialization of the present LAMP kit for early detection of footrot got major advantage as it could be performed by non-specialist with minimal training at the field level which can avoid difficult and time consuming procedures. Screening of the samples with LAMP for both $D$. nodosus and $F$. necrophorum will help in epidemiological investigation to establish the causal association of $F$. necrophorum with $D$. nodosus in causing footrot in sheep and goat. It will also facilitate early, fast and accurate on-farm diagnosis of infection and help to reduce spread of the disease through adoption of suitable control and preventive measures including vaccination or new management strategies.

\section{Declarations}

\section{Funding information}


The authors are thankful to Sri Venkateswara Veterinary University, Tirupati, Andhra Pradesh, for the financial support for conducting above research.

\section{Authors Contribution :}

VK conceived and designed research. MK conducted experiments. VK analyzed data. MK wrote the manuscript. VK read corrected and approved the manuscript.

\section{Compliance with ethical standards}

Conflict of interest The authors declare that they have no conflict of interest.

Ethics Declaration : No animal ethical issues are involved in this research.

Funding information : Funding is by SVVU Tirupati.

Conflicts of interest : Not subjected to any conflicts of interest.

Ethical approval : No animal ethical issues are involved in the current research.

Consent to participate : Not applicable.

Consent for publication : Not applicable.

Availability of data and material : Not applicable.

Code availability : Not applicable

\section{References}

1. Amoako, K. K., Goto, Y. and Shinjo, T. (1993) Comparison of extracellular enzymes of Fusobacterium necrophorum subsp. necrophorum and Fusobacterium necrophorum subsp. funduliforme. Journal of Clinical Microbiology., 31: 2244-2247.

2. Cheetham, B. F., Tanjung, L. R., Sutherland, M., Druitt, J., Green, G. Mc., Farlane, J., Bailey, G. D., Seaman, J. T. and Katz, M. E. (2006) Improved diagnosis of virulent ovine footrot using the intA gene. Veterinary Microbiology.,116 (1-3): 166-174.

3. Das, A., Babiuk, S. and Mclntosh, M. T. (2012) Development of a Loop-Mediated Isothermal Amplifiation Assay for Rapid Detection of Capri pox viruses. Journal of Clinical Microbiology., 50 (5): 1613.

4. Dhungyel, O. P., Whittington, R. J. and Egerton, J. R. (2002) Serogroup specific single and multiplex PCR with pre-enrichment culture and immuno-magnetic bead capture for identifying strains of D.nodosus in sheep with footrot prior to vaccination. Molecular cel. Probes., 16 (4): 285-296.

5. Elleman, T. C. (1988) Pilins of Bacteroides nodosus: molecular basis of serotypic variation and relationships to other bacterial pilins. Microbiol Rev., 52:233-247. 
6. Farooq, S., Wani, S. A., Hussain, I. and Bhat, M. A. (2010) Prevalence of ovine footrot in Kashmir, India and molecular characterization of Dichelobacter nodosus by PCR. Indian Journal of Animal Science., 80 (9): 826-830.

7. Harsha, Y., Kumar, N., Chaitanya, R. K. and Sujatha, K. (2019) Detection and characterization of Fusobacterium necrophorum LktA gene from footrot of sheep and goats in Andhra pradesh. P.G. thesis submitted to SVVU, Andhra Pradesh.

8. Johnson, A. M. A., Dasgupta, I. and Sai Gopal, D. V. R. (2014) Development of loop mediated isothermal amplification and SYBR green real-time PCR methods for the detection of Citrus yellow mosaic badnavirus in citrus species. Journal of virological methods., 203:9-14.

9. Kamachi, K., Toyoizumi-Ajisaka, H., Toda, K., Soeung, S. C., Sarath, S., Nareth, Y., Horiuchi, Y., Kojima, K., Takahashi, M. and Arakawa, Y. (2006) Development and evaluation of a loop mediated isothermal amplification method for rapid diagnosis of Bordetella pertussis infection. Journal of Clinical Microbiology., 44 (5): 1899-1902.

10. Kennan, R. M., Dhungyel, O. P., Whittington, R. J., Egerton, J. R. and Rood, J. I. (2001) The type IV fimbrial subunit gene (fimA) of Dichelobacter nodosus is essential for virulence, protease secretion, and natural competence. Journal of Bacteriology., 183: 4451-4458.

11. Kennan, R. M., Wong, W., Dhungyel, O. P., Han X, Wong, D., Parker, D. and Rood, J. I. (2010) The subtilisin-like protease AprV2 is required for virulence and uses a novel disulphide-tethered exosite to bind substrates. PLoS Pathogens., 6(11): e1001210.

12. Kumar, A., Peterson, G., Nagaraja, T. G. and Narayanan, S. (2013) Research Paper Outer membrane proteins of Fusobacterium necrophorum subsp. necrophorum and subsp. funduliforme.

13. Kumar, N. V., Karthik, A., Vijayalakhsmi, S. and Sreenivasulu, D. (2015) Phylogenetic analysis of Dichelobacter nodosus serogroup-specific fimA gene from ovine footrot in Andhra Pradesh. Veterinary World., 8(5): 567.

14. Kumar, N. V., Sreenivasulu, D. and Karthik, A. (2016) Identification and characterization of Dichelobacter nodosus serogroup $\mathrm{H}$ from ovine footrot in India. Anaerobe., (40): 100-102.

15. Kumar, N. V., Karthik, A., Sreenivasulu, D., Vijayalakshmi, S. and Bhaskar, M, V. (2013) Incidence of footrot in sheep during summer at Thottambedu and BN Kandriga mandals of Chittoor District, Andhra Pradesh. International Journal of Advanced Science and Technology., Res. 3(4): 248-256.

16. Kumar, N. V., Karthik, A. and Sreenivasulu, D. (2016) Detection of Dichelobacter Nodosus and Fusobacterium Necrophorum From Footrot of Sheep and Goats in Andhra Pradesh. Indian Veterinary Journal., 93(07): 39-41.

17. La Fontaine, S., Egerton, J. R. and Rood, J. I. (1993) Detection of Dichelobacter nodosus using speciesspecific oligonucleotides as PCR primers. Veterinary Microbiology., 35(1-2): 101-117.

18. Mori, Y., Nagamine, K., Tomita, N. and Notomi, T. (2001) Detection of loop-mediated isothermal amplification reaction by turbidity derived from magnesium pyrophosphate formation. Biochemical and Biophysical Research Communications., 289: 150-154.

19. Narayanan, S. K., Nagaraja, T. G., Chengappa, M. M. and Stewart, G. C. (2001) Cloning, sequencing, and expression of the leukotoxin gene from Fusobacterium necrophorum. Infection and Immunity., 69(9): 
5447-5455.

20. Notomi, T., Okayama, H., Masubuchi, H., Yonekawa, T., Watanabe, K., Amino, N. and Hase, T. (2000) Loop-mediated isothermal amplification of DNA. Nucleic acids Research., 28(12): e63-e63.

21. Parida, M., Sannarangaiah, S., Dash, P. K., Rao, P. V. L. and Morita, K. (2008) Loop mediated isothermal amplification (LAMP): a new generation of innovative gene amplification technique; perspectives in clinical diagnosis of infectious diseases. Reviews in Medical Virology., 18: 407-421.

22. Radhika, B., Kumar, N. V. and Sreenivasulu, D. (2016) Detection of Clostridium perfringens alpha toxin gene in lambs by loop mediated isothermal amplification. Veterinary world., 9(1): 60.

23. Saxena, A., Pal, V., Tripathi, N. K. and Goel, A. K. (2019) A real-time loop mediated isothermal amplification assay for molecular detection of Burkholderia mallei, the aetiological agent of a zoonotic and re-emerging disease glanders. Acta Tropica., 194: 189-194.

24. Sun, D. B., Wu, R., Guo, D. H., He, X. J., Zheng, J. S., Wang, J. F. and Guo, T. T. (2011) Combination of Dichelobacter nodosus LAMP with Fusobacterium necrophorum LAMP for detecting hoof swabs from dairy cattle footrot. African Journal of Microbiology Research., 5(6): 667-670.

25. Tan, Z. L., Nagaraja, T. G. and Chengappa, M. M. (1992) Factors affecting the leukotoxin activity of Fusobacterium necrophorum. Veterinary Microbiology., 32: 15-28.

26. Tan, Z. L., Nagaraja, T. G. and Chengappa, M. M. (1996) Fusobacterium necrophorum infections: virulence factors, pathogenic mechanism and control measures. Veterinary Research Communications., 20(2): 113-140.

27. Thomas, N., Joseph, S., Alex, R., Raghavan, K. C., Radhika, G., Anto, L. and Mohan, S. G. (2011) Genetic variation in resistance to caprine foot rot by Dichelobacter nodosus in goats of Kerala, India. Biotechnology Animal Husbandary., 27: 235-240.

28. Vinod, K. N. (2012) Molecular characterization of Clostridium perfringens toxin types isolated from sheep of Andhra Pradesh. Ph.D. thesis submitted to SVVU, Andhra Pradesh.

29. Wang, D., Yu, J., Wang, Y., Zhang, M., Li, P., Liu, M. and Liu, Y. (2020) Development of a real-time loopmediated isothermal amplification (LAMP) assay and visual LAMP assay for detection of African swine fever virus (ASFV). Journal of Virological Methods., 276: 113775.

30. Wani, S. A., Samanta, I. and Kawoosa, S. (2007) Isolation and characterization of Dichelobacter nodosus from ovine and caprine footrot in Kashmir, India. Research Veterinary Science., 83:141-144.

31. Zhang, J., Zhu, J., Ren, H., Zhu, S., Zhao, P., Zhang, F. and Gong, X. (2013) Rapid visual detection of highly pathogenic Streptococcus suis serotype 2 isolates by use of loop-mediated isothermal amplification. Journal of Clinical Microbiology., 51(10): 3250-3256.

32. Zheney, M., Kaziyev, Z., Kassenova, G., Zhao, L., Liu, W., Liang, L. and Li, G. (2018) Real-time fluorescence loop-mediated isothermal amplification assay for direct detection of egg drop syndrome virus. BMC Veterinary Research., 14(1): 1-8.

\section{Figures}




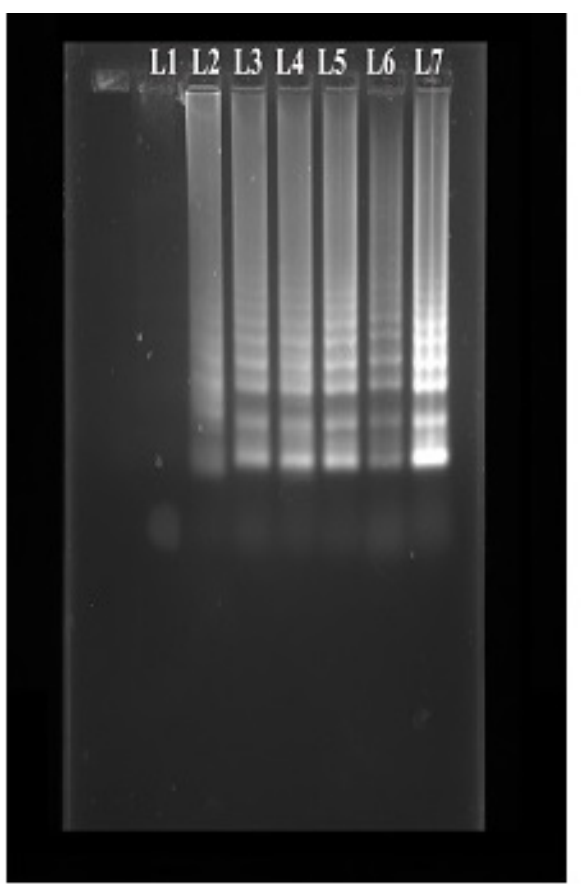

Fig 1 Soreening of clinical samples for F. necophorum by LAMP

Ll : Negative control L2: Positive control L3-L7 : Fidd samples

Figure 1

See image above for figure legend. 


\section{L2 L3 LA L5 L6}

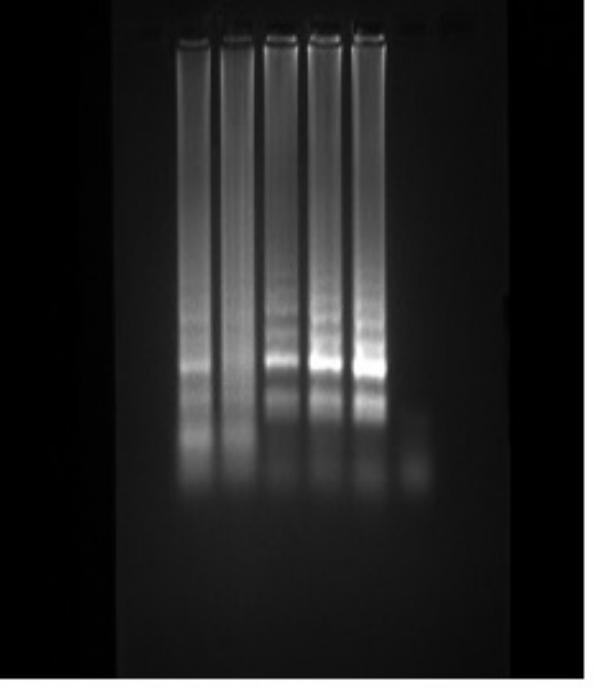

Fig. 2 Screning of dinical samples for

D. nodosus by LAMP

L6 : Negativecontrol

L5 : Positive control

L1-4 : Filed samples

Figure 2

See image above for figure legend. 


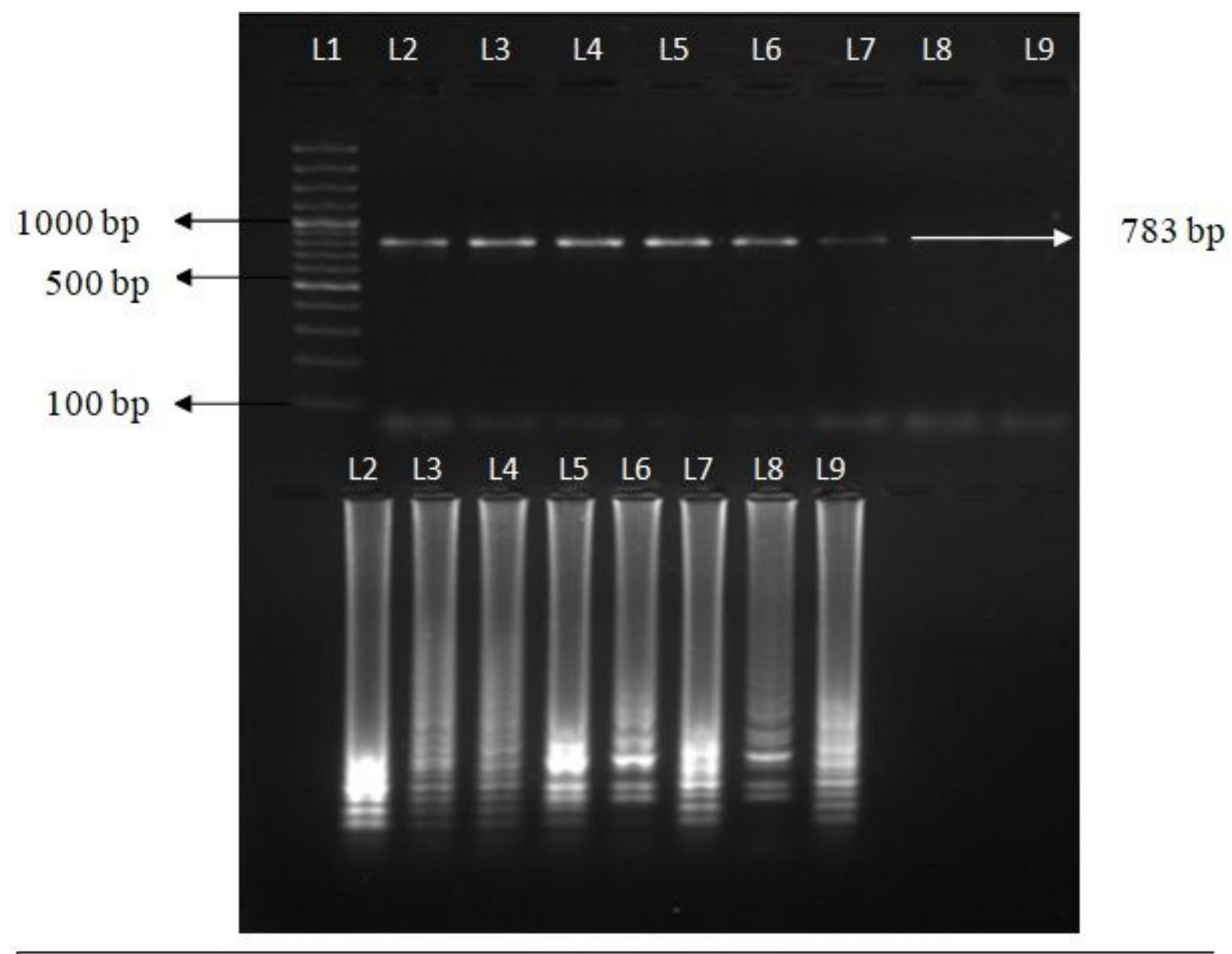

Fig 3 Comparison of efficacy LAMP with PCR targeting 16s rRNA gene of $D$. nodosus serial dilutions of Template DNA.

$\begin{array}{llll}\text { Upper } & \text { : PCR } & \text { Gel } 2 & \text { : LAMP } \\ \text { L1 } & \text { : 100bp ladder } & \text { L2 } & \text { : positive Control } \\ \text { L2 } & \text { : positive Control } & \text { L3-L9 } & \text { : positive samples } \\ \text { L3-L } & \text { : Positive samples } & \text { L10 } & \text { : Negative Control } \\ \text { L10 } & \text { : Negative Control } & & \end{array}$

Figure 3

See image above for figure legend. 


\section{$\begin{array}{lllllllll}\text { L1 } & \text { L2 } & \text { L3 } & \text { L4 L5 } & \text { L6 } & \text { L7 } & \text { L8 } & \text { L9 }\end{array}$}

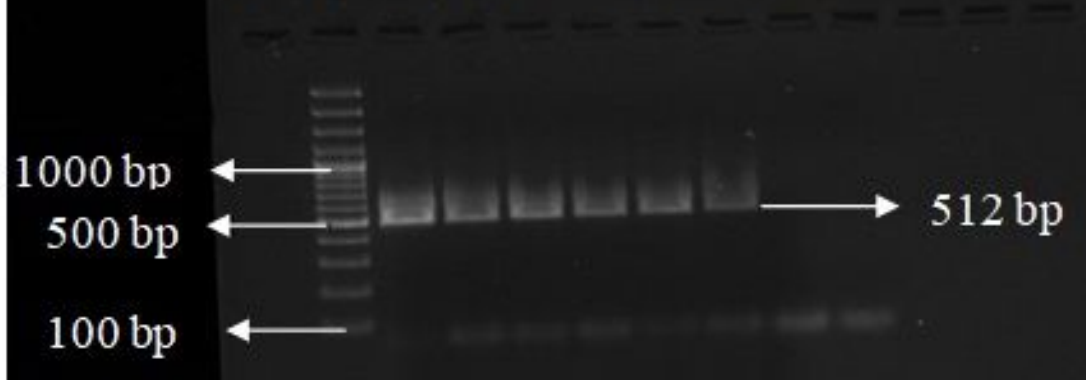

L1 L2 L3 L4 L5 L6 L7 L8

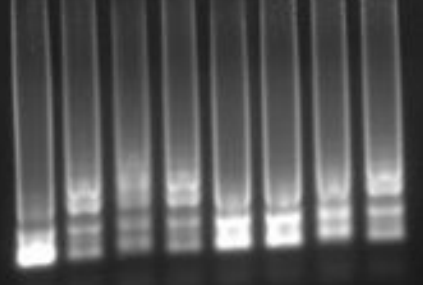

Fig 4: Comparison of efficacy of LAMP with PCR targeting Ikt $A$ gene of F. necrophorum with serial dilutions of Template DNA.
Upper
: PCR
L1
: Negative Control
L2 : 100bp ladder
Lower
: LAMP
L3 to L8 : positive for PCR at 512 bp
$L 9$ and $L 10$
: Negative for PCR
L1 : positive control
L2-L8 : Positive samples

Figure 4

See image above for figure legend. 


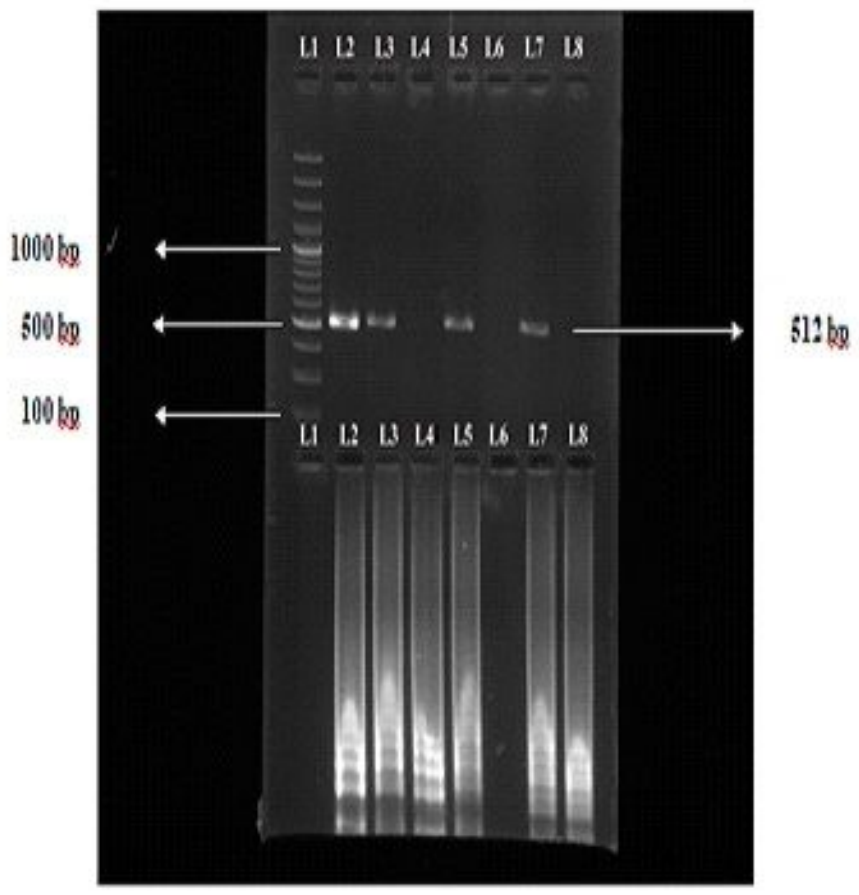

Fig. 5 Amplicons of $l$ t A gene of $F$ necrophorum from clinical samples screened by both PCR and LAM.

Ll (Upper) : $100 \mathrm{bp} \mathrm{ladder}$

L2 (Upper \&Lower) : Positive Control

L3, L5, L7( Upper \&lover) : Positive for both PCRand LAMP

L4, L8(Upper \&lower) : : Negative for PCRand positive for LAMP

L6 (Upper \& lower) : Negative for both PCR and LAMP

Figure 5

See image above for figure legend. 